\title{
Pengembangan Sistem Transaksi Penjualan dan Pembelian Pada Peron Sawit Menggunakan Aplikasi
}

\author{
Rizki Novendra ${ }^{1}$, Syahtriatna $^{2}$, M. Sadar ${ }^{3}$, Viranda Anisa $^{4}$ \\ ${ }^{1,2,3}$ Universitas Lancang Kuning \\ (19Program Studi Sistem Informasi Fakultas Ilmu Komputer Universitas Lancang Kuning) \\ ('Program Studi Sistem Informasi Fakultas Ilmu Komputer Universitas Lancang Kuning) \\ ( ${ }^{3}$ Program Studi Teknik Informatika Fakultas Ilmu Komputer Universitas Lancang Kuning) \\ ( ${ }^{4}$ Program Studi Sistem Informasi Fakultas Ilmu Komputer Universitas Lancang Kuning) \\ (Jl. Yos Sudarso KM. 8 Rumbai, Pekanbaru, Riau, telp. 0811753 2015) e-mail: \\ ${ }^{1}$ rizkinovendra@unilak.ac.id, ${ }^{2}$ eet@ unilak.ac.id, ${ }^{3}$ sadarzen@ unilak.ac.id
}

\begin{abstract}
Abstrak
Penerappan teknologi sistem informasi pada proses bisnis perusahaan merupakan salah satu strategi untuk mengatasi permasalahan pada perusahaan. Penelitian ini bertujuan untuk mengatasi beberapa permasalahan serta mendukung peningkatan dari sisi efisiensi proses bisnis CV. Saragih 3 Brother.Untuk merealisasikan tujuan tersebut, dalam penelitian ini telah menggunakan metode waterfall. Yang mana metode tersebut memiliki beberapa tahapan meliputi analisis, desain, implementasi, testing dan maintenance. Setiap tahapan tersebut memiliki definisi dan fungsi yang berbeda, namun saling terkait antara satu dan yang lain demi mengasilkan suatu aplikasi komputer yang dapat digunakan pada bisnis perusahaan CV. Saragih 3 Brother. Aplikasi peron sawit yang telah dihasilkan pada penelitian ini memberikan telah memberikan dampak positif bagi proses bisnis perusahaan. Dampak positif meliputi kecepatan dalam proses transaksi penjualan dan pembelian dari 5 menit pertransaksi menjadi 1 menit dan pembuatan laporan yang sebelumnya memakan waktu 3 jam menjadi 10 menit
\end{abstract}

Kata kunci: sistem informasi, waterfall, proses bisnis

\begin{abstract}
Applying information system technology to the company's business processes is one of the strategies to overcome problems in the company. This study aims to overcome several problems and support the improvement in terms of efficiency of business processes CV. Saragih 3 Brothers. To realize this goal, in this study we have used the waterfall method. Which method has several stages including analysis, design, implementation, testing and maintenance. Each of these stages has different definitions and functions, but are interrelated between one and the other in order to produce a computer application that can be used on the company's business CV. Brother Saragih 3. The application Peron Sawit that has been produced, in this study provides a positive impact on the company's business processes. The positive impact includes the speed in the sales and purchase transaction process from 5 minutes of transaction to 1 minute and making reports that previously took 3 hours to 10 minutes
\end{abstract}

Keywords: information system, waterfall, business process. 


\section{Pendahuluan}

Pesatnya perkembangan teknologi memicu perusahaan dari yang berskala besar hingga kecil untuk menggunakan teknologi sistem informasi. Dalam suatu perusahaan berskala kecil maupun besar tersebut pasti memiliki proses bisnis. Rangkaian aktifitas yang terstruktur tersebut tentunya memiliki perbedaan antara satu dengan yang lainnya, tergantung dari jenis bisnis yang dijalani oleh perusahaan. Salah satu bisnis yang tersebar di beberapa Kabupaten Provinsi Riau yaitu Peron sawit. Peron sawit merupakan tempat penampungan dan pembelian buah sawit.

CV. Saragih 3 Brother merupakan salah satu yang menjalani bisnis peron sawit. CV.S3B terletak di desa kota lama kecamatan Rengat Barat, Kabupaten Indragirihulu Provinsi Riau. Seperti peron sawit pada umumnya, CV.3SB memiliki 10 orang BHL (buruh harian lepas) yang bertugas mengangkat atau bongkar muat buah kelapa sawit. Tidak hanya memiliki 10 orang BHL, CV.3SB juga memiliki dua orang admin yang bertugas melakukan proses transaksi jual dan beli sawit. Selain melakukan proses transaksi jual dan beli, admin juga bertugas membuat laporan penjualan, pembelian dan pengeluaran dalam jangka waktu perhari, perminggu dan perbulan, yang dilakukan secara manual.

Proses transaksi dan pembuatan laporan yang dilakukan secara manual memberikan dampak ketidak akuratan hasil yang diperoleh. Terlebih lagi CV.S3B setiap bulannya memiliki transaksi penjualan dan pembelian buah kelapa sawit mencapai angka ratusan ton. Untuk menghindari permasalahan tersebut dapat dilakukan suatu peningkatan pada sisi pemanfaatan teknologi informasi. Dengan pemanfaatan dan penerapan sistem pada transaksi yang telah ada, diharapkan akan memberi dampak pada keakuratan data dan menghidari dari kerugian financial.

Salah satu peningkatan yang dapat dilakukan pada peron sawit adalah membangun suatu aplikasi sentral. Dimana aplikasi tersebut dapat melakukan transaksi berupa perhitungan yang akurat. Berdasarkan informasi di lapangan, proses transaksi yang paling utama pada CV.S3B adalah perhitungan bruto, tara, dan netto yang kemudian akan dikurangi dengan potongan persen sesuai ketetapan pemilik peron dan dikalikan dengan harga beli buah sawit per kilogram. Tidak hanya dapat melakukan proses transaksi jual dan beli, Aplikasi peron tersebut juga dituntut dapat memfasilitasi admin dalam membuat laporan secara otomatis.

\section{Penelitian Terkait}

Beberapa penelitian yang telah pernah dilakukan terkait dengan permasalahan dan tujuan penelitian yang akan diteliti antara lain:

- Lisnawati Christian (ComTech 2015) meneliti tentang analisis sistem informasi akuntansi penjualan dan pembelian yang memberikan dampak kemudahan bagi pihak managemen memperoleh informasi dengan cepat dan mudah serta penyajian laporan secara cepat dan akurat. Hasil dari penelitian ini berupa model aplikasi sistem informasi akuntansi penjualan dan pembelian spare part pada perusahaan jasa mobil secara umum

- Indah Ayu Septia Ningrum, Dodon T. Nugrahadi, Ichsan Ridwan (KLIK 2016) meneliti tentang perancangan sistem parkir yang memberikan dampak efisiensi. Dampak efisiensi dapat dilihat dari segi waktu atau kecepatan dalam mendeteksi keberadaan mobil pada slot parkir yang tersedia. Sistem tersebut dapat menampilkan aktifitas parkir pada aplikasi berbasis web seperti kondisi lahan parkir kosong

- Stephanie Surja, Lius Steven Sanjaya (ComTech 2015) melakukan penelitian tentang analisa dan perancangan sistem jasa pengiriman logistik pada PT Rapex Wahana bertujuan untuk menganalisa kebutuhan perusahaan dalam proses bisnis jasa pengiriman logistik. Tujuan dari penelitian ini meminimalisir kehilangan atau kesalahan data yang sering terjadi karena penyimpanan data transaksi yang dilakukan secara manual dan tidak terorganisir. Hasil dari analisa akan digunakan sebagai dasar pengembangan sistem informasi terintegrasi untuk mencapai tujuan perusahaan terhadap otomatisasi proses bisnis pengiriman. 
- Hanny Juwitasari, Marlene Martani, Arya Nata Gani Putra (ComTech 2015) melakukan penelitian tentang analisis sistem informasi akuntansi pembelian dan persediaan pada PT. XYZ. Tujuan dari penelitian ini yaitu meminimalisir terjadinya kesalahan dalam pencatatan data transaksi oleh karyawan dan memudahkan perusahaan dalam pengendalian terhadap persediaan barang

\section{Metode Penelitian}

a. Kerangka Pikir

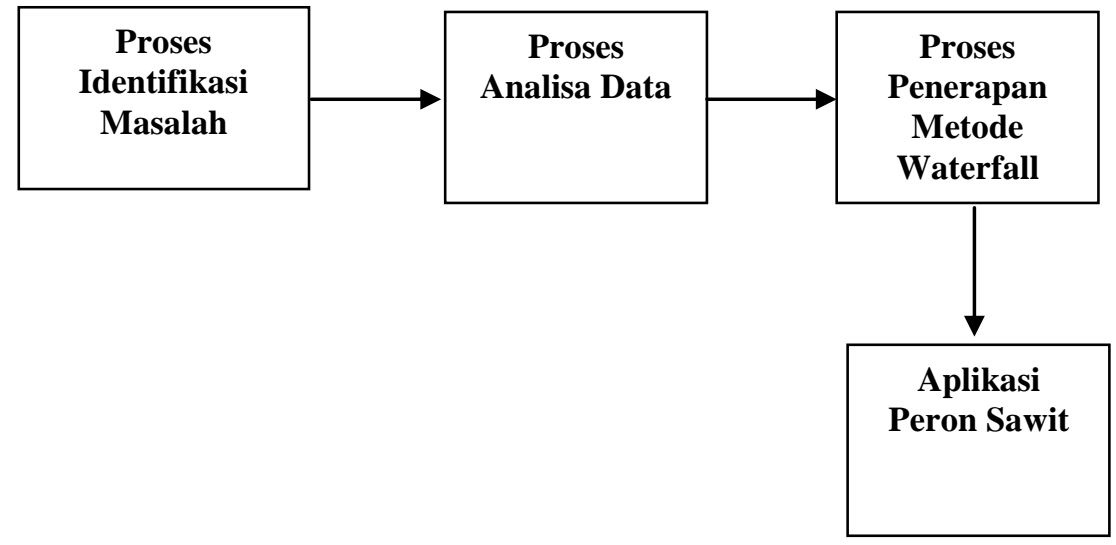

\section{b. Bahan Penelitian}

Untuk dapat menyelesaikan suatu permasalahan, sebelumnya dibutuhkan beberapa data serta informasi yang meliputi data transaksi penjualan, pembelian dan proses bisnis yang sedang berjalan. Data tersebut didapatkan pada perusahaan dengan cara melakukan proses wawancara dengan pihak terkait yang memiliki pengetahuan pada bidangnya masing - masing.

\section{c. Alat Penelitian}

Untuk menunjang proses penelitian pengembangan aplikasi penjualan dan pembelian pada peron sawit, peneliti menggunakan beberapa alat yang meliputi UML dan Visual Studio C\#. Unified Modeling Langage (UML) digunakan untuk membuat pemodelan design aplikasi. Sedangkan Visual Studio C\# merupakan pemrograman yang dipilih untuk membuat aplikasi pada penelitian ini.

\section{d. Metode Penelitian}

Pada penelitian ini menggunakan metode Waterfall. Model waterfall merupakan proses pembangunan perangkat lunak secara sequensial, dimana alur atau progres dari projek dianggap mengalir semakin kebawah (mirip air terjun) melalui daftar tahapan yang harus dijalankan agar berhasil membangun software komputer. Berikut metode waterfall

\section{Requirements Analysis}

Tahapan ini lebih dikenal sebagai software requirement spesification (SRS). Disini dijelaskan tentang deskripsi perilaku perangkat lunak yang akan dikembangkan dengan melibatkan tim analis sistem. Penjelasan atau deskripsi dari sistem akan dilampirkan dalam bentuk usecase. Yang mana usecase diagram akan memberikan gambaran interaksi pengguna dengan perangkat lunak.

Design

Tahapan desain merupakan proses perencanaan dan pemecahan masalah solusi 
perangkat lunak. Tahapan ini berimplikasi pada pengembang perangkat lunak dan designer untuk merencanakan solusi yang meliputi design algoritma, arsitektur perangkat lunak, konsep database serta graphical user interface design

Implementation

Pada tahapan implementasi ini mengacu kepada realisasi kebutuhan bisnis dan desain spesifikasi menjadi wujud program yang dapat dieksekusi. Dengan kata lain tahapan ini adalah dimana kode sebenarnya ditulis dan disusun menjadi operasional, atau proses pengubahan blueprint kelingkungan produksi

\section{Testing}

Tahapan testing ini juga dikenal sebagai proses verifikasi dan validasi. Proses tersebut meliputi pengecekan software dan hardware yang memenuhi persyaratan spesifikasi. Aplikasi yang telah dibuat tentunya akan dilakukan pengecekan dalam bentuk uji coba. Dalam proses uji coba inilah nantinya akan diketahui suatu program running well apa tidak. Tidak hanya itu, dibutuhkan kecocokan antara spesifikasi hardware dan software untuk mendukung suatu aplikasi berjalan dengan baik

Maintenance

Merupakan proses modifikasi solusi perangkat lunak setelah pengiriman dan penyebaran untuk memperbaiki output, kesalahan atau eror dan meningkatkan kinerja serta kualitas.

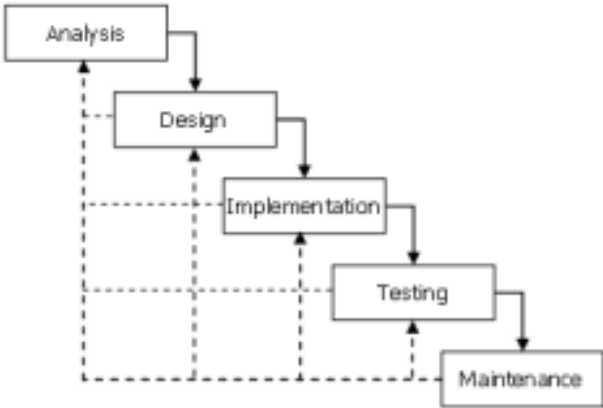

Gambar 1 Model waterfall 


\section{Hasil dan Pembahasan}

\section{Analisis}

Tahapan analisis merupakan tahapan awal untuk memulai suatu pengembangan aplikasi berdasarkan model waterfall. Pada tahapan ini akan dijelaskan deskripsi perilaku perangkat lunak dalam bentuk usecase diagram. Berikut usecase diagram dari CV. Saragih 3 Brother :

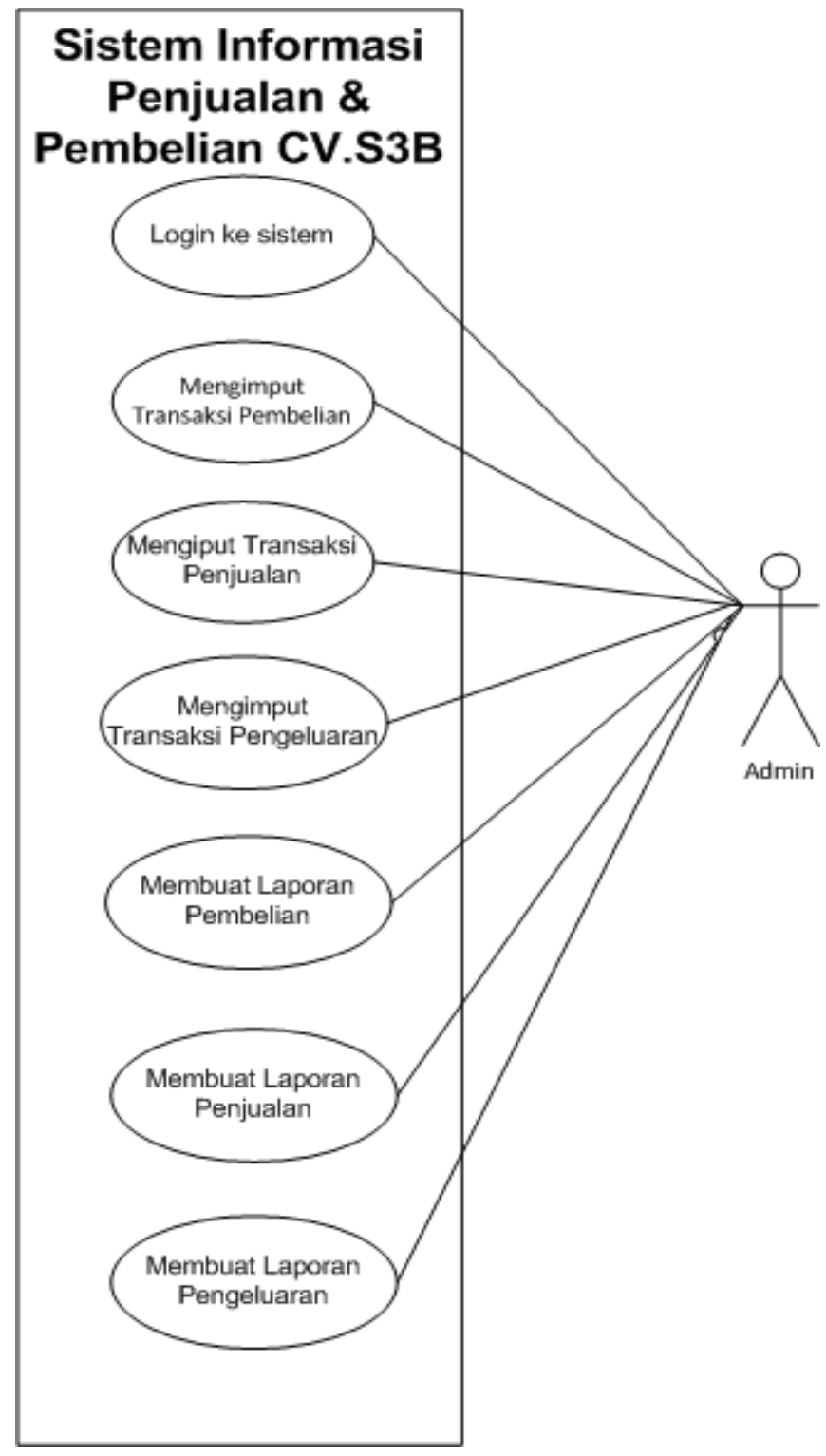

Gambar 2. Usecase CV. S3B

\section{Deskripsi Singkat Usecase Diagram}

- Login Sistem

Langkah pertama pada aplikasi yaitu admin melakukan login ke sistem. Pada aplikasi terdapat login form dimana admin diwajibkan untuk mengisi id dan password yang telah didaftarkan pada database

- Mengimput transaksi pembelian

Pada proses ini admin akan mengimput beberapa value kedalam textbox 
seperti tanggal, nama, bruto, tara, netto, potongan persen, netto akhir, potongan akhir dan harga per kilogram

- Mengimput transaksi penjualan

Pada transaksi penjualan, admin bertugas mengimput data tanggal, nama supir dan total penjualan

- Mengimput transaksi pengeluaran

Form transaksi pengeluaran berisi textbox yang harus diisi oleh admin, berikut beberapa data yang harus diinput admin seperti tanggal, spsi, amprah langsir amprah tronton dan operasional

- Membuat laporan pembelian

Admin dapat membuat laporan pembelian secara otomatis. Lapora pembelian biasanya dibuatt dalam jangka waktu perhari, perminggu, perbulan dan pertahun.

- Membuat laporan penjualan

Tidak hanya laporan pembelian, laporan penjualan juga dapat dilakukan admin secara otomatis dengan menggunakan tools pada sistem. Laporan penjualan sama halnya dengan laporan pembelian, yaitu dapat dibuat dalam jangka waktu perhari, perminggu, perbulan dan pertahun

- Laporan pengeluaran

Laporan ini merupakan laporan terakhir yang dapat dibuat oleh admin. Sama halnya dengan laporan sebelumnya, admin dapat membuat laporan pengeluaran secara otomatis bedasarkan jangka waktu yang dapat ditentukan sendiri

\section{Hasil}

Seperti apa yang telah dijelaskan sebelumnya, hasil dari penelitian ini berupa suatu aplikasi yang dapat melakukan beberapa proses transaksi dan membuat laporan. Berikut akan ditampilkan hasil implementasi dari perancangan user interface yang telah dibuat sebelumnya :

\section{A. Login Form}

Pada login form ini, admin dapat mengimput username dan password. Kemudian sistem secara otomatis melakukan validasi atau pengecekan kesesuaian data inputan admin dengan data yang terdapat pada database. Apabila inputan admin tidak sesuai dengan database akan muncul message box yang berisi pesan kesalahan

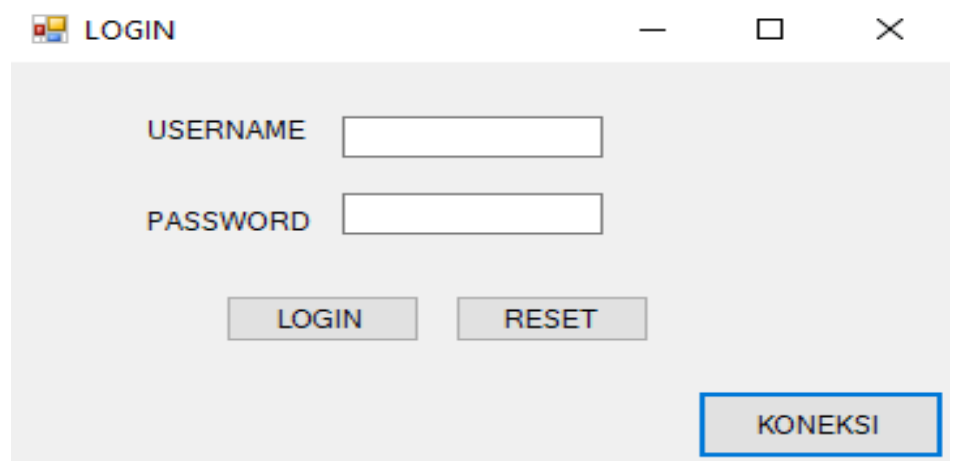

Gambar 3. Login Form

\section{B. Transaksi Pembelian}

Dibawah ini merupakan form pembelian. Pada form pembelian ini admin bertugas mengisi data yang akan diinput kedalam database. 


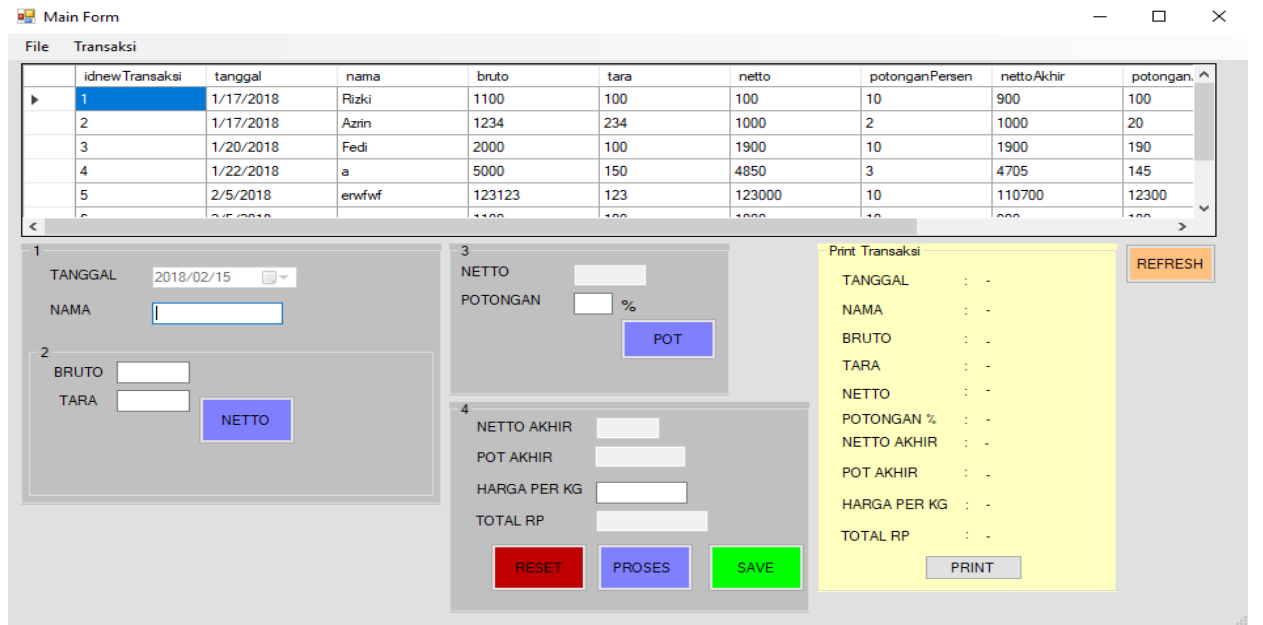

Gambar 4. Transaksi Pembelian

Dapat dilihat terdapat textbox yang pertama yaitu nama. Selanjutnya terdapat textbox bruto, tara dan netto. Textbox netto merupakan hasil dari perhitungan bruto dikurang tara. Sedangkan untuk textbox netto akhir merupakan hasil perhitungan netto dikurang potongan persen dan textbox total merupakan hasil perkalian antara netto akhir dengan harga per $\mathrm{kg}$. Selanjutnya admin dapat melakukan print out transaksi pembelian dengan cara klik button print. Aplikasi secara otomatis terhubung dengan thermal printer untuk melakukan perintah print transaksi. Berikut contoh hasil print out transaksi pembelian :

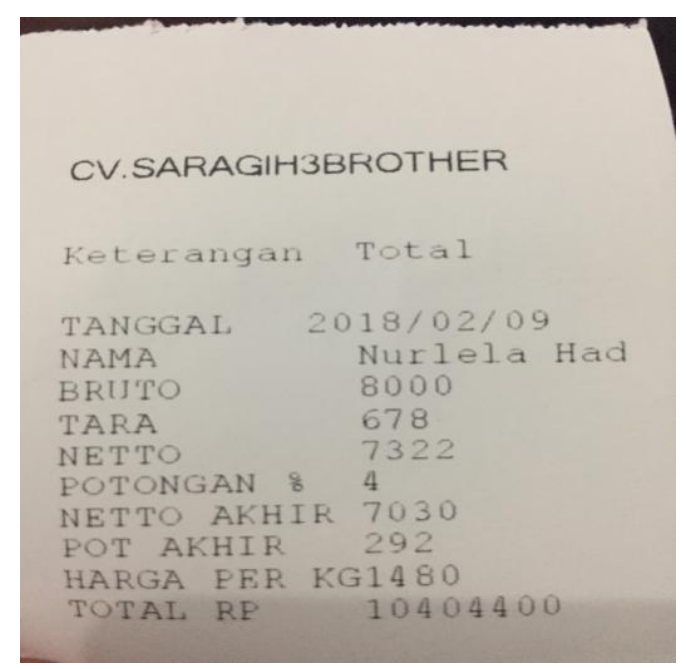

Gambar 5. Print Out Transaksi Pembelian

\section{Transaksi Penjualan}

Berikut gambar form transaksi penjualan 


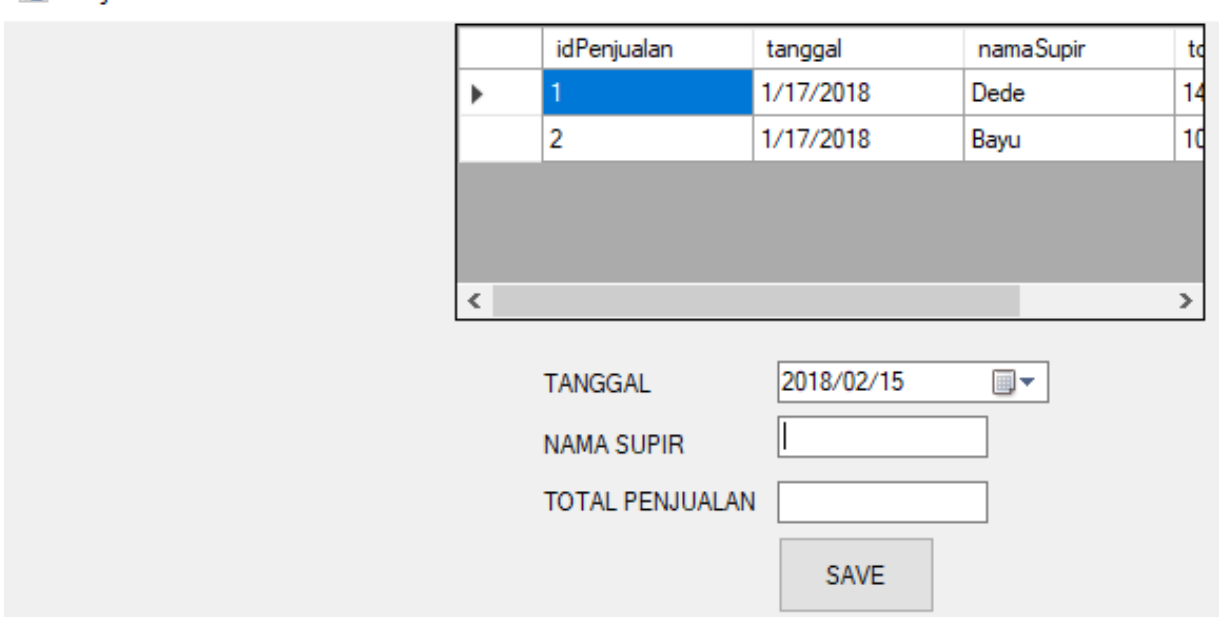

\section{Gambar 6. Transaksi Penjualan}

Dapat dilihat pada form transaksi penjualan, terdapat beberapa textbox yang harus disi oleh admin, yaitu tanggal, nama supir dan total penjualan

\section{Transaksi Pengeluaran}

Pada transaksi pengeluaran terdapat beberapa perhitungan yang dilakukan sistem secara otomatis. Yaitu pada textbox spsi, amprah langsir, amprah tronton dan opersional. Semua inputan tersebut akan dijumlahkan secara otomatis yang kemudian hasilnya terdapat pada textbox total. Berikut gambar transaksi pengeluaran :

吅 Pengeluaran

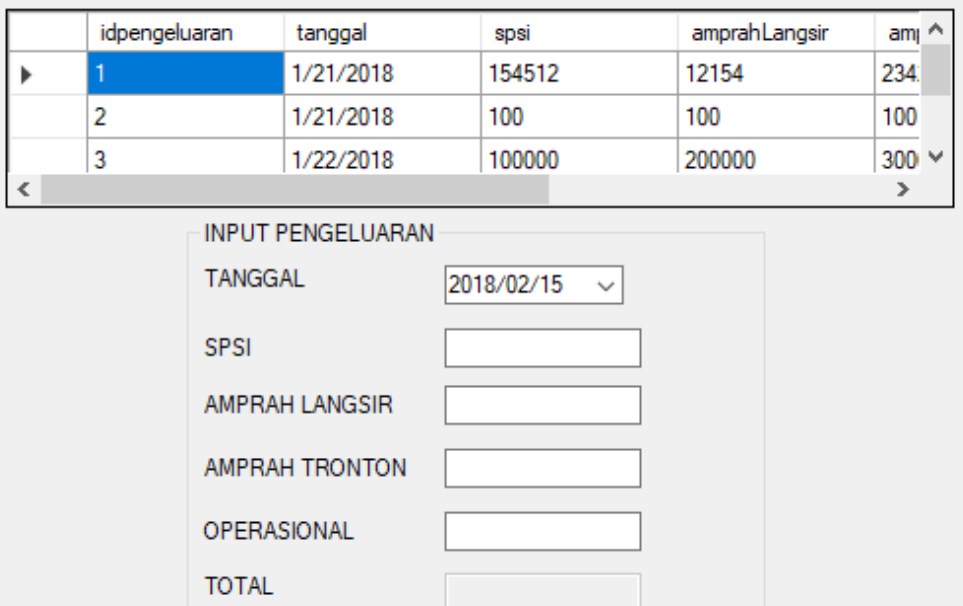

Gambar 7. Transaksi Pengeluaran 


\section{E. Laporan Pembelian}

Seperti yang telah disebutkan sebelumnya, admin dapat membuat laporan pembelian secara otomatis, berdasarkan jangka waktu yang ditentukan. Berikut gambar parameter value dan laporan pembelian :

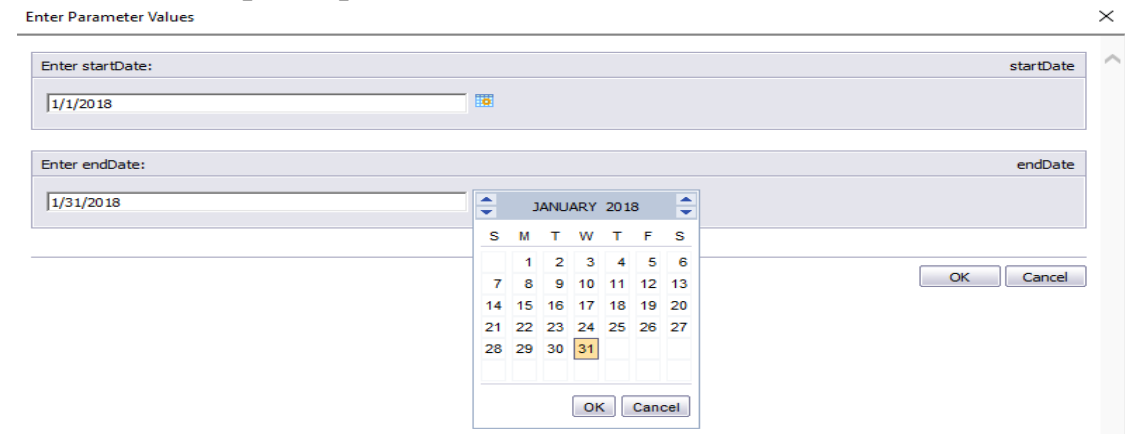

Gambar 8. Parameter Value

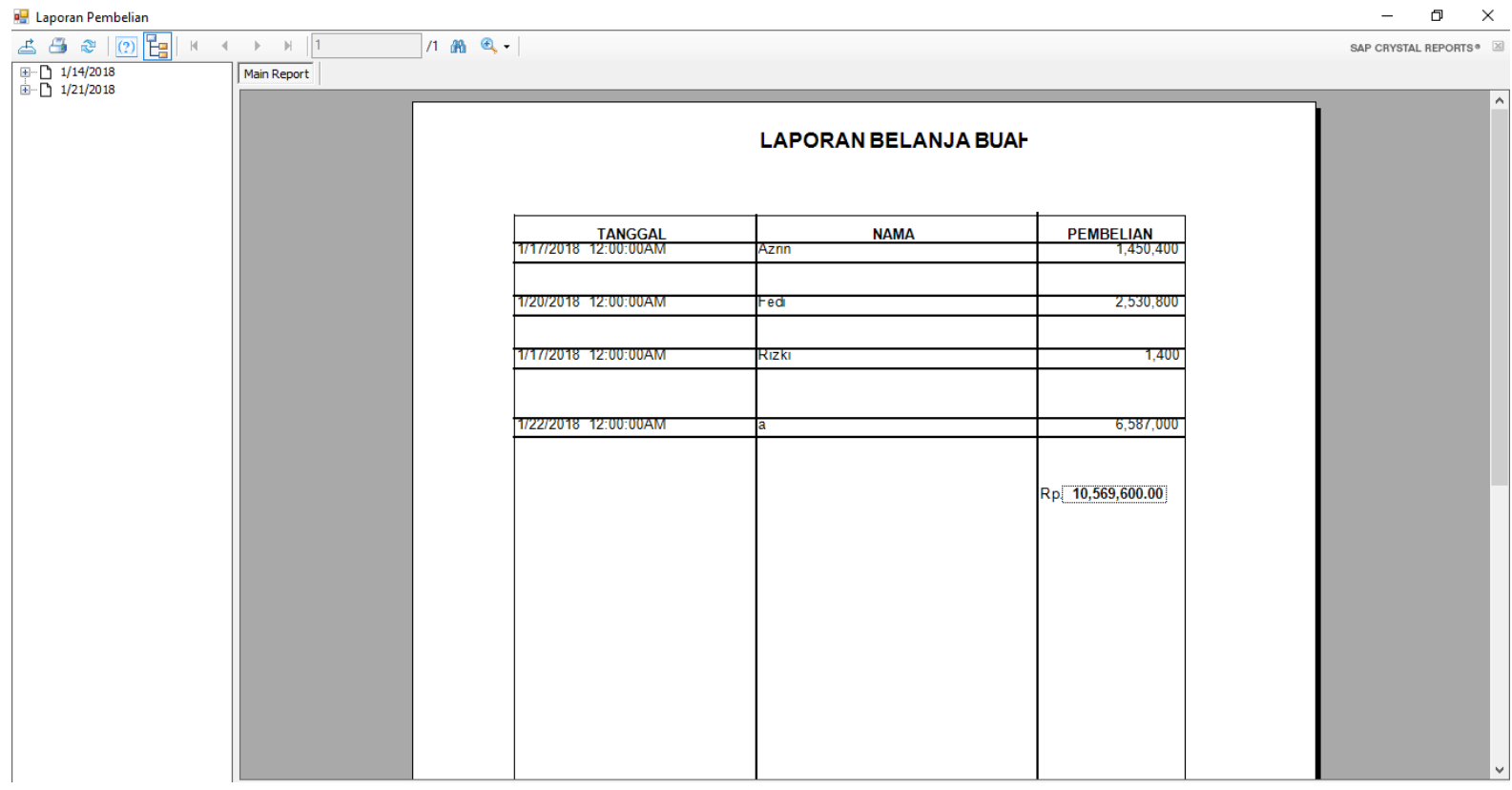

Gambar 9. Laporan Pembelian

\section{F. Laporan Penjualan}

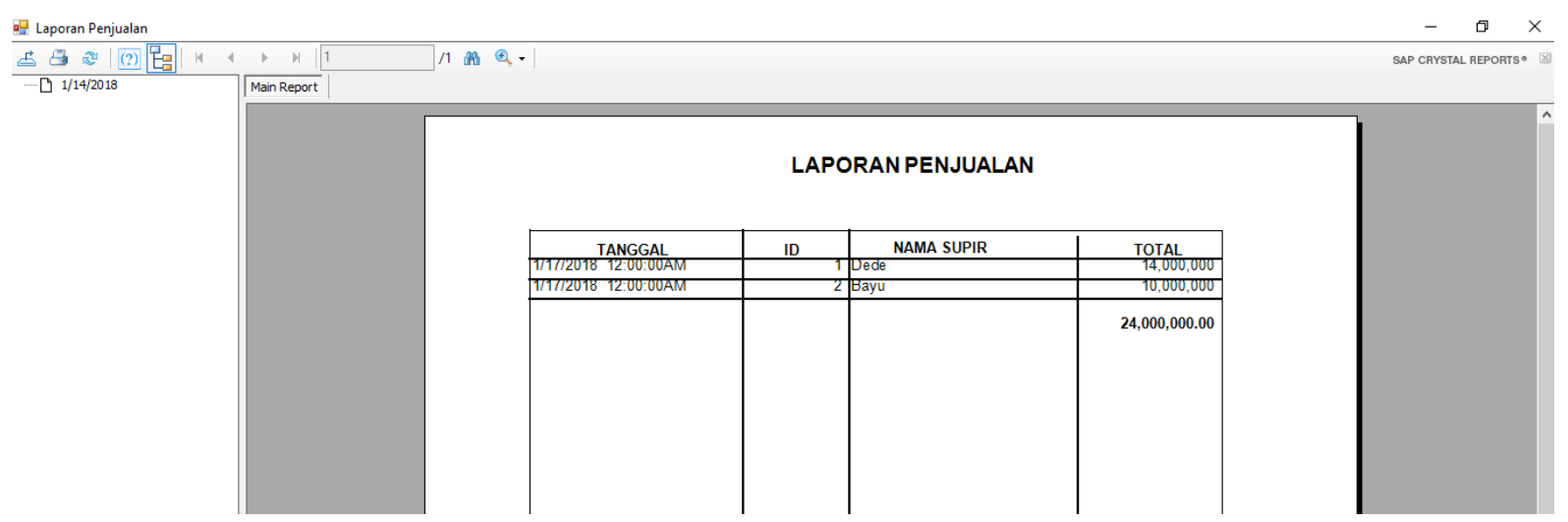

Gambar 10. Laporan Penjualan 


\section{G. Laporan Pengeluaran}

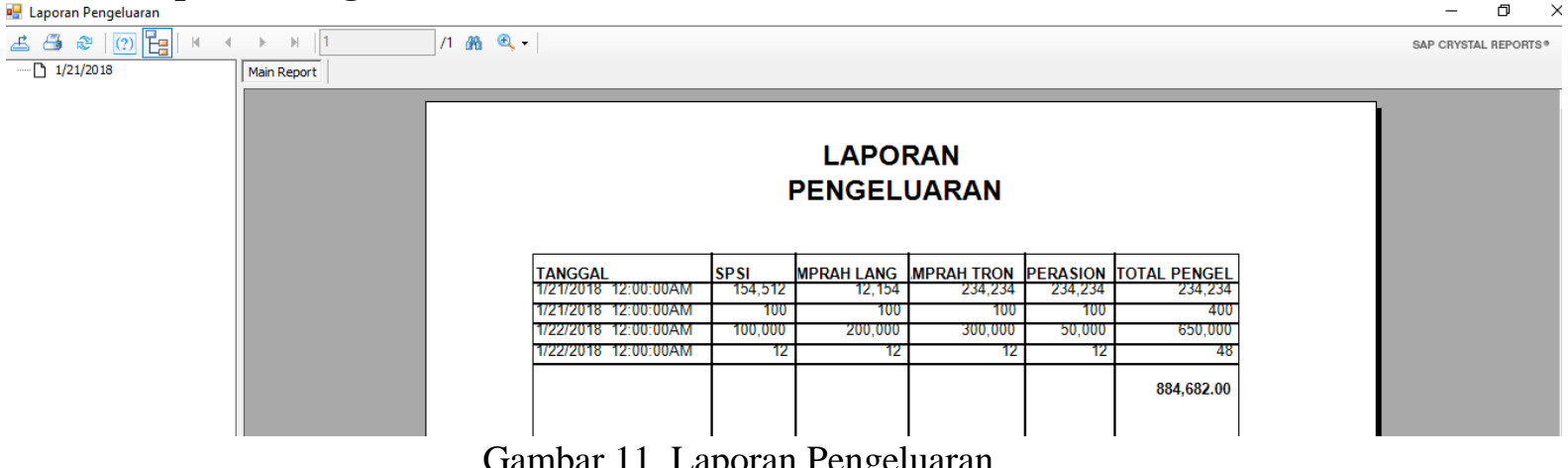

Gambar 11. Laporan Pengeluaran

\section{Kesimpulan}

Penelitian ini telah memilih metode waterfall untuk menjawab permasalahan yang telah dirumuskan sebelumnya. Seperti yang telah kita ketahui terdapat beberapa permasalahan pada proses pengembangan aplikasi peron sawit ini. Permasalahan tersebut meliputi ketidak akuratan data dan perhitungan serta lambatnya proses transaksi. Permasalahan tersebut disebabkan oleh kurang telitinya admin dalam melaksanakan segala proses transaksi dan laporan yang masih manual.

Dengan menggunakan aplikasi peron sawit ini membantu dalam proses transaksi menjadi lebih cepat. Untuk memperoleh hasil transaksi pembelian sebelumnya karyawan melakukan perhitungan secara manual yaitu $:$ bruto - tara $=$ netto. Netto - potongan persen $=$ netto akhir. Netto akhir * harga per $\mathrm{kg}=$ total. Sebelum menggunakan aplikasi rata-rata waktu yang dibutuhkan untuk melakukan satu transaksi pembelian yaitu \pm 5 menit. Durasi dari proses transaksi tersebut tergantung pada besarnya satuan bruto dan tara. Setelah menggunakan aplikasi, waktu yang dibutuhkan untuk melakukan proses transaksi pembelian hanya memerlukan waktu kurang dari satu menit. Proses percepatan tersebut tidak hanya terjadi pada transaksi pembelian. Tetapi juga pada transaksi penjualan dan pengeluaran.

Proses selanjutnya yang paling banyak memakan waktu yaitu pembuatan laporan pembelian, penjualan dan pengeluaran. Pembuatan laporan tesebut biasanya dilakukan satu bulan sekali dengan rata-rata ratusan ton total transaksi. Proses pembuatan laporan sebelum menggunakan aplikasi yaitu dengan cara mengumpulkan catatan transaksi kemudian menjumlahkan nominal transaksi tersebut secara manual. Untuk menyelesaikan proses pembuatan laporan tersebut memakan waktu \pm 3 jam. Setelah menggunakan aplikasi, waktu yang dibutuhkan untuk membuat laporan tersebut tidak lebih dari 10 menit. Dari perbandingan waktu pembuatan laporan tersebut dapat disimpulkan bahwa dengan menggunakan aplikasi memberikan dampak efisiensi serta memudahkan karyawan dalam membuat laporan secara otomatis.

Dari sisi aplikasi masih ada satu laporan yang belum terimplementasikan, yaitu laporan pendapatan. Laporan tersebut berkaitan dengan beberapa laporan lainnya yang dibuat oleh admin CV.S3B. Laporan pendapatan adalah laporan yang dibuat secara otomatis melalui perhitungan antara laporan penjualan dikurang dengan laporan pengeluaran dan laporan pembelian.

Aplikasi peron sawit tidak hanya dapat digunakan oleh CV. S3B saja. Namun seluruh peron sawit yang memiliki proses perghitungan yang sama dapat menggunakan aplikasi ini demi meningkatkan efisiensi, keakuratan data serta perhitungan 


\section{Daftar Pustaka}

[1] Aliminssyah \& Padji, 2005. Kamus Istilah Manajemen, Penerbit Yrama Widya, Bandung

[2] Bassil, Y. (2012). A Simulation Model for the Waterfall Software Development Life Cycle, 2(5).

[3] Chairul Marom , (2002), Sistem Akuntansi Perusahan Dagang, Edisi Kedua, Penerbit Grasindo, Jakarta

[4] Juwitasary, H., Martani, M., Nata, A., \& Putra, G. (2015). PEMBELIAN DAN PERSEDIAAN PADA PT . XYZ, 6(1), 96-108.

[5] Christian, L. (n.d.). MODEL APPLICATION OF ACCOUNTING INFORMATION SYSTEMS OF SPARE PARTS SALES AND PURCHASE ON CAR SERVICE COMPANY, 371-380.

[6] Justin G. longenecker, dkk. 2006 Kewirausaahaan Manajemen Usaha Kecil. Jakarta: Salemba Empat

[7] Maharsi, S. (n.d.). Pengaruh perkembangan teknologi informasi terhadap bidang akuntansi manajemen, 127-137.

[8] Bentley, Lonnie D \& Whitten, Jeffrey L. (2007). Systems Analysis and Design for the Global Enterprise, 7th Edition, International Edition., New York: McGrawHill

[9] Surja, S., \& Sanjaya, L. S. (n.d.). ANALYSIS AND DESIGN INFORMATION SYSTEM LOGISTICS DELIVERY SERVICE IN PT REPEX WAHANA, 505-513. 